\title{
Comparative Study of Pupils' Academic Performance between Private and Public Primary Schools
}

\author{
Sunday B. Adeyemi ${ }^{1, *}$ \\ ${ }^{1}$ Department of Arts and Social Science Education, Faculty of Education, Osun State University, Ipetu-Ijesa campus, \\ Ipetu - Ijesa, Osun State, Nigeria \\ *Correspondence: Department of Arts and Social Science Education, Faculty of Education, Osun State University, \\ Ipetu-Ijesa campus, Ipetu - Ijesa, Osun State, Nigeria. Tel: 234-803-392-9549. E-mail: sambanky07@gmail.com
}

Received: June 4, 2014

Accepted: June 21, $2014 \quad$ Online Published: July 31, 2014

doi:10.5430/wje.v4n4p55

URL: http://dx.doi.org/10.5430/wje.v4n4p55

\begin{abstract}
This paper compares pupils' academic performance between the private and public primary schools. The sample, made up of 240 pupils were randomly selected from the private and public primary schools in Ilesa East and West Local Government Council Areas of Osun State, Nigeria. Two instruments were used. A structured questionnaire and Pupils' Achievement Test (PAT) in three core-subject areas of the Primary School Curriculum namely: English Language, Mathematics and Social Studies. While the questionnaire was used to collect relevant bio- data of the respondents, the instrument on achievement tests (PAT) was used to collect data on students' performance in the three subjects involved in the study. Data were analyzed using frequency count, simple percentages and Z-test. Results showed that pupils in the private primary schools performed better than their counterparts in the public schools and therefore call for improvement in the public schools to enhance the learning opportunity of the vast majority of pupils attending the public schools.
\end{abstract}

Keywords: pupils; academic performance; public schools; private schools

\section{Introduction}

Learning has been so much associated with the school that some people almost think that learning goes on only in schools. This view of learning has been greatly reinforced by such reference to schools as institutions of learning and to Universities, Polytechnics and College of Education as institutions of higher learning (Okoye, 1987). There is no doubting the fact that much learning goes on in school. The school is particularly and specifically arranged so as to facilitate effective learning. Unfortunately the poor condition of our schools, particularly the primary schools today in the nation raises a lot of anxiety. A cursory look at these school in spite of government efforts reveals schools dominated by dilapidated buildings, school void of good furniture and equipment, schools where instructional materials are either not provided or are inadequate; school that are under-staffed; schools, where teachers salaries and allowances are not promptly paid, schools that have not been inspected for the last 15 years; schools where there are no discipline among other things.

The government, and especially the parents are very much concerned with the quality and volume of learning acquired by their children, wards and citizens as this is related to the quality and quantity of the contribution which the individual can make to his immediate family, community and the nation as a whole. (Thorndike, 1931).

Several studies by Sociologist, Psychologists and Educationists showed that the type of schools a learner attends has profound influence on his academic achievement. For instance, Bibby and Peil (1974) noted that children who attended private primary schools performed better than pupils in public schools. This view is also supported by Lioyd (1966) as he contended further that the public schools which saw education as good thing, tended to leave the question of educational success or failure in the hands of the public and their parents. This implies that the business of education is not taken with all the seriousness it demands in the public schools. This of course is what may be regarded as the general apathy of the citizenry to government's owned business or property. A situation that has resulted in lackadaisical attitude of government's workers, including teachers in the public schools tend to believe that an intelligent child would succeed automatically at school without any active assistance coming from them. 
In a study jointly carried out by the Federal Government of Nigeria, UNICEF and UNESCO in 1977 to monitor the learning achievement of primary school pupils throughout the Federation, it was shown that most of the private schools had means in the three areas tested higher than the national means and that of their public counterpart. Similarly, Yoloye (1998) while assessing the situation of education in Osun State, compared the quality of education in five states of the federation namely, Lagos, Ogun, Ondo, Osun and Oyo. He compared performance between urban and rural schools; private and public schools, as well as between male and female primary school pupils. He concluded that while Osun State comes last in almost all the sub-sector analyzed, the only cheering exception is in the private schools where it performed better than other states and indeed exceeded the grand mean. He did not give reasons for low or high achievement.

Fafunwa (1981) however, observed that access to qualitative instruction, thorough supervision in schools, relevant instructional materials, standard school buildings, less-crowded classrooms, conducive school environment are some of the major school variables influencing pupils, academic attainment. He concluded that in areas where private schools are well established, drop-out rates would be drastically reduced and pupils academic performance enhanced. This he said may be due to availability of resources and more importantly to the fact that teachers are positively motivated.

In a study carried out in the U.S. by Lubienski and Lubienski (2006), they compared academic achievement among charter, private and public schools. One of the major findings from this study showed that private schools scored higher than charter and public schools. In a related study carried out also in the U.S. by Braun, Jenkins and Grigg (2006), they compared the performance of pupils in private and public schools in both reading and mathematics involving grades 4 and 8 , results showed that the private schools performed better than the public schools not only in reading and mathematics, but also in the two grades (4th \& 8th) involved in the study. Overall, findings indicated that the average private school mean score was higher than the average public school mean score, and that the difference was statistically significant.

However, in the study comparing students' academic performance in business studies in public and private Junior Secondary School Certificate Examinations (JSSCE) in Ovia South West Local Government Council Area of Edo State, Nigeria, conducted by Igbinedion and Epumepu (2011), it was revealed that there was significant difference in the academic performance in business studies between the public and private schools from 2008 to 2011. Results further showed that the percentage performance trend of public schools were higher than those of the private both males and females.

Consequent upon the discussion above, more parents and guardians who can afford it are daily withdrawing their children and wards from the public schools to the private fee-paying primary schools despite its expensive nature even in this hard time. Many of the private schools are growing bigger and fatter at the expense of the public ones whose enrolment is daily dwindling. It is in this context that this study is set out to compare pupils' academic performance between the private and public primary schools in Ilesa East and Ilesa West Local Government Council Areas of Osun State, Nigeria.

The study therefore sought to find out if there is any difference in pupils' academic attainment between private and public primary schools in the two local government council areas involved in the study. It also highlighted the causes of such differences in academic achievement between the private and public schools and suggested measures to rectify the differences so discovered.

\subsection{Research Questions}

Answers were provided to the following questions in the study:

i) Will there be any difference in academic performance between private and public primary school pupils?

ii) What variables are responsible for this difference(s)?

ii) What measures can be put in place to improve the situation?

\subsection{Hypothesis}

One main null hypothesis that was formulated and tested in this study is as stated hereunder:

Ho1: There will be no statistically significant difference in pupils' academic performance between private and public primary schools. 


\section{Methodology}

\subsection{Research Design}

The design adopted for the study is the descriptive survey research design, which is consistent with the nature of the problem being investigated, as it allows the researcher to reach out to a larger number of the target population.

\subsection{Population and Sample}

The population for this study is made up of pupils in both private and public primary schools in Ilesa (East and West) local government council areas of Osun State. Only pupils in primary four were deliberately selected for this study. This is because most pupils leave the primary school system from primary four, especially in the private schools, having gained admission into the junior secondary schools, since the first school leaving certificate examination is no longer made compulsory for them (FRN, 2004). The sample drawn using the simple random sampling technique consisted of 240 pupils, 120 respondents were selected each from the private and public primary schools with equal representation of males and females.

\subsection{Instruments}

Two instruments were developed and used. The first was a structured questionnaire to collect information on the biographical data of the respondents and information on the general conditions in the schools. The second instrument was Pupil Achievement Test (PAT) in three subject areas namely: English Language, Mathematics and Social Studies. The three subjects used for this instrument constitute part of the "Core subjects" in the primary school curriculum. Each of the three achievement tests contains twenty (20) standardized question items, meant to assess the pupils' performance in the three subjects..

\subsection{Data Collection Procedure}

The researcher made use of 25 of his students on teaching practice to help administer the instrument on the subjects on the same day after proper orientation. There was $100 \%$ return rate of the questionnaires.

\subsection{Data Analysis}

In analyzing the data so collected from the instruments, the researcher made use of frequency count and simple percentages in dealing with the first instrument. And having graded the pupils' test, calculated the mean scores for all the subjects involved in the study, used the mean percentage scores to categorize the pupils into ability groups of :

i) Above average

ii) Average and

iii) Below average

The researcher thereafter applied the Z-test to compare pupils' performance between private and public primary schools.

\section{Results}

Table 1. Private School Pupils’ Performance

$(\mathrm{N}=\mathbf{1 2 0})$

\begin{tabular}{lll}
\hline Grades & f & $\mathbf{\%}$ \\
\hline Above Average & 88 & 73.3 \\
Average & 21 & 17.5 \\
Below Average & 11 & 9.2 \\
Total & 120 & 100.00 \\
\hline
\end{tabular}

Table 1 above shows the performance of private primary schools pupils in the test administered. They were graded into various ability groups, having computed the mean (average) score for all the respondents involved

From the table, it is clearly revealed that 88 representing $73.3 \%$ of the respondents in the private primary schools scored above average, while $17.5 \%$ and $9.2 \%$ of the subjects scored averagely and below the average marks respectively. 
Table 2. Public School Pupils’ Performance

$(\mathrm{N}=120)$

\begin{tabular}{lll}
\hline Grade & F & $\mathbf{\%}$ \\
\hline Above Average & 37 & 30.8 \\
Average & 14 & 11.7 \\
Below Average & 69 & 57.5 \\
Total & 120 & 100.00 \\
\hline
\end{tabular}

Table 2 displays the performance of the public primary school pupils. 37 (30.8\%) of the subjects scored above the average mark. The performance of $14(11.7 \%)$ of them were adjudged to be average, while 69 of them representing $57.5 \%$ scored below the average mark.

Table 3. Comparative Pupils’ Performance between Private and Public Primary Schools

$(\mathrm{N}=\mathbf{2 4 0})$

\begin{tabular}{lllllll}
\hline Schools & \multicolumn{2}{l}{ Above Average } & Average & \multicolumn{2}{l}{ Below Average } \\
\cline { 2 - 7 } & $\mathrm{f}$ & $\%$ & $\mathrm{~F}$ & $\%$ & $\mathrm{f}$ & $\%$ \\
\hline Private & 88 & 73.3 & 21 & 17.5 & 11 & 9.2 \\
Public & 37 & 30.8 & 14 & 11.7 & 69 & 57.5 \\
\hline
\end{tabular}

From table 3 above, $73.3 \%$ of the pupils from the private school scored above average, as against $30.8 \%$ in the public school in same category. In the average category, it was $17.5 \%$ and $11.7 \%$ of the pupils from private and public schools respectively. While it was only $9.2 \%$ of the pupils from private school that scored below average, it was as much as $57.5 \%$ of the pupils from public schools.

\section{Testing of Hypothesis}

There will be no statistically significant difference in pupils' academic performance mean scores between private and public schools.

Table 4. Z-test Comparison of Difference between Mean Scores of Pupils in Private and Public Primary Schools

\begin{tabular}{llllllll}
\hline Schools & $\mathrm{X}$ & $\mathrm{S} . \mathrm{D}$ & $\mathrm{N}$ & $\mathrm{DF}$ & Standard Error & Z-Calculated & Z-critical \\
\hline Private & 23.0 & 4.12 & 120 & & & & \\
& & & & 238 & 0.75 & 11.0 & 1.96 \\
Public & 14.7 & 7.20 & 120 & & & &
\end{tabular}

Since the calculated $\mathrm{Z}$ value of 11.0 is greater than critical value of (1.96), we reject the null hypothesis and accept the alternative hypothesis, that is, there is difference in the academic performance of pupils in private and public primary schools. It is not just a difference, but statistically significant as evident in table 4 . This implies that the pupils in private schools performed better than their counterparts in the public primary schools.

\section{Discussion}

It is obvious from the results presented above, that pupils in the private primary schools performed better than their counterparts in the public schools, lending credence to earlier study reported (Braun, Jenkins \& Grigg, 2006; Lubienski \& Lubienski, 2006; and Yoloye, 1988;). This of course could be attributed to a number of factors. Evidence showed that while both types of schools may be said to be at par in terms of quality of staff, conditions of school buildings and provision of instructional materials, the private school may be said to be better off in several other areas. It was found that NCE holders dominated the work force in both schools with Bachelor's degree holders found in few private schools.

While it was similarly revealed that most of the public schools were dominated by dilapidated buildings, majority of the private ones visited were housed in uncompleted buildings - many of which may not be said to be conducive for learning. Most of them in fact had no playing ground to take care of the physical aspect of the child's development. This however, is at variance with the finding of an earlier study (Busari, 1989) which concluded that public schools are better staffed and had better instructional materials than the private schools. 
However, the private schools may be said to have excelled in such areas as: efficient instructional encounter in the classroom as a result of frequent and thorough supervision, dynamic school administration, frequent class assignments, prompt payment of teachers' salaries and allowances, mutual parent-school relationship, positive pupil-teacher interactions, absence of teachers industrial actions, provision of adequate furniture and the maintenance of the standard teacher-pupil ratio among others all of which stimulate effective learning in the children.

The situation in the public schools on the other hand had deteriorated to the extent that pupils carry their chairs and desks to school on daily basis. Some even sit on the floor in many classrooms. Most schools are under-staffed and until recently, teachers were owed salaries arrears. All these are capable of wielding negative influence on pupils' learning.

\section{Conclusion and Recommendations}

From the findings of this study, it may be concluded that pupils in the private primary schools performed better than their counterparts in the public schools due to certain factors.

It is, however, hoped that the public schools could be improved and be brought back to glory and be made competitive with the private ones if the following recommendations are religiously implemented. To this end, the public schools must be adequately staffed, enough furniture provided and schools regularly inspected. Universal Basic Education Commission (UBEC) may be advised to embargo all extravagant spending by its members of staff. Thus the public primary schools would be adequately equipped to compete with the private school currently gaining ground. Otherwise, there may be a time when the public primary schools would not enjoy patronage if this trend continues unabated.

\section{Acknowledgement}

My profound gratitude goes to significant individuals and organizations who directly or indirectly had contributed to the success of this work. I want to thank in a special way Prof. J. Ademokoya of the Faculty of Education, University of Ibadan, Nigeria and Prof. Kola Adeyemi, Faculty of Education, University of Benin, Nigeria for their valuable contributions to the success of the study. I also appreciate my colleagues: Dr. F. A. Yusuf, who is the Head of my department, Dr. A.A. Aderogba for their useful pieces of advice while the study lasted and the departmental Secretary who assisted with the typing of the work. My special and deep appreciation goes to other renowned scholars, experts, researchers, authors and organizations from whose works this study has greatly benefitted.

Thank you all.

\section{References}

Bibby, J., \& Peil, M. (1974). Secondary education in Ghana Private enterprise and social selection. London: Longman.

Braun, H., Jenkins, F., \& Grigg, W. (2006). Comparing private schools and public schools using hierarchical linear modeling (NCES 2006 - 461). U.S. department of education, National Centre for Education Statistics, Institute of Education Science. Washington, DC: U.S. Government Printing Office. Nces.ed.gov/nationsreportcard/pdf/studies/2006

Busari, O. O. (1989). Science Programme evaluation: A study of resources and classroom experience in Lagos State Primary Schools. In Ehiametalor, E. T.

Fafunwa, B. A. (1981). Private education in Ghana: Private enterprise and social selection. London: Longman.

Federal Republic of Nigeria (2004). National Policy on Education (rev.). Lagos. NERC Press.

FGN, UNICEF, \& UNESCo. (1977). Assessment of Primary 4 pupils in Nigeria. Lagos: FGN/UNICEF/UNESCO.

Igbinedion, V.I., \& Epumepu, E.A. (2011). A comparison of students' academic performance in business studies in public and private junior secondary school certificate examinations (JSSCE) in Ovia South West Local Government Council Area of Edo State. Technical and Vocational Education Journal (TVEJ), 3(1), 42-53.

Izuagie, M. A., \& Olaitan, S. O. (ed). Implementation of National Policy on education: Theoretical and Empirical Analysis. Benin City: NERA Publications. 
Lioyd, P.C. (1966). Power and Independence: perception of inequality. London: Routledge and Kegan Paul.

Lubienski, C., \& Lubienski, S.T. (2006). Charter, private, public schools and academic achievement: New Evidence from NAEP Mathematics Data. Nepc.colorado.edu/files/EPRU-0601-137-ow1\%

Thorndike, E. L. (1931). Human Learning: New York: Appleton-Century Crofts. http://dx.doi.org/10.1037/11243-000

Yoloye, E. A. (1998, March). Education in Osun State. Keynote address at the $20^{\text {th }}$ anniversary workshop of the Osun State College of Education, Ilesa. 